\title{
Shading and Air Flow Analysis on Selected Residential Buildings in Al-Bayda City, Libya
}

\author{
Mohammed Ali S. Ali ${ }^{1}$, Kozan Uzunoglu², Çimen Özburak ${ }^{3}$ \\ ${ }^{1}$ Faculty of Architecture, Near East University, Near East Avenue, Nicosia 99010, North Cyprus \\ ${ }^{2}$ Faculty of Architecture and Engineering, Bahçeşehir Cyprus University, Bahçeşehir Cyprus University Alayköy Campus, \\ Nicosia 99010, North Cyprus \\ ${ }^{3}$ Faculty of Architecture, Near East University, Near East Avenue, Nicosia 99010, North Cyprus
}

Corresponding Author Email: kozan.uzunoglu@baucyprus.edu.tr

https://doi.org/10.18280/ijsdp.160307

Received: 12 March 2021

Accepted: 20 May 2021

\section{Keywords:}

energy consumption, passive design, orientation, air movement, shadow

\begin{abstract}
A lot of energy is required to provide a comfortable interior with air conditioning systems. The use of high energy in buildings has made an essential contribution to climate change and air pollution. It is crucial for energy efficiency to reduce energy consumption. Applying the architectural principles of climatic design can provide thermal comfort in residential buildings. In this research, an analytical study was conducted on the climate factors that affect the energy consumption in the residential buildings in Al-Bayda, Libya. Eight buildings were randomly selected. The impact of solar energy, orientation, and wind factors that affect the climatic comfort on the selected residential buildings were considered as the leading indicators for improving energy consumption. These topics were studied comprehensively on the chosen buildings, and outcomes of the analysis were evaluated. Users gave answers to the questions regarding energy consumption, protection and utilization from the sun and air currents, and the physical insulation status of the building during the interviews. Independently of these, the results of airflow and shade analysis based on theories of passive design principles for each building have been revealed. It was observed that the answers of users and analytical results were consistent with each other. In the end, simple constructional applications that can prevent high energy use were recommended for future architectural designs. In this way, extensive use of air conditioners and thus air pollution, which has become one of the significant problems in Libya's cities, can be reduced to a certain extent.
\end{abstract}

\section{INTRODUCTION}

To achieve energy-saving housing, we have to reconcile with the environment which is an essential source of concern for the modern man. So we cannot ignore environmental factors and the need to avoid collisions with them because they are the strategic choice to preserve humanity's future. Our approach to the environment and its preservation of pollutants provide energy consumption and create a healthy climate free of pollution, both outside and inside the building, because pollution inside the house is more dangerous than external pollution. Human beings live in temporal intervals inside buildings rather than exterior, and windows are closed most of the time. Frequent use of air conditioning contributes to reducing the sun's entry and airflow inside the building, which contributes to the spread of some diseases.

As it is known, the orientation of buildings, solar control, choice and use of materials, use of water elements and form of building, air-movement control, and daylight control are the main factors that are considered in passive design strategies [1, 2]. The strategies are interpreted in several ways. Some of them are mentioned in Table 1 [3-6].

Alexandre et al. in their study, which is about a residential project proposal, considered high thermal insulation of the envelope, efficient windows, mechanical ventilation with heat recovery, airtightness and reduction of thermal bridges as parameters of passive house design strategies, and proved their importance by using software programs [7]. Ramos et al. [8] and Gong [9] mention that "orientation" is one of the most important factors to be addressed in passive design. Because orientation influences air movements in and around buildings, solar radiation loads, topography, nearby buildings, etc. The focus is on the importance of orientation, solar shading, and air movements in this context. Daylight effect is not included in the context, and it is not considered in the analysis of selected buildings.

A large number of recently built residential buildings in Libya need a great deal of energy. Unpredictable power consumption in Libya has led to the need for a pause to correct the way energy is treated, which can lead to many problems. Besides, an increase in population correspondingly increases energy consumption. Therefore, energy is the future problem, making it the top scientific and applied research in various parts of the world. So, the need arises to find ways to create a comfortable natural environment with passive systems.

Passive systems are a kind of architectural layout focusing on energy efficiency, which aims to create a climatically comfortable environment for people without the use of any mechanical and electrical system. The primary aim of passive design is to obtain thermal comfort in the living spaces by controlling desired and undesired airflows together with sun within architectural arrangements [10]. Building performance 
has priority in passive designs. Design is made by considering criteria such as building geometry, space arrangement, sun and wind direction. The aim is to minimize the building energy consumption [11].

Table 1. The topics of the passive design strategies are presented by some researchers [3-6]

\begin{tabular}{|c|c|c|c|}
\hline \multicolumn{4}{|c|}{ PASSIVE DESIGN STRATEGIES } \\
\hline Hasim Altan et al. & $\begin{array}{l}\text { Passive design } \\
\text { handbook }\end{array}$ & $\begin{array}{c}\text { Passive solar design } \\
\text { strategies }\end{array}$ & $\begin{array}{c}\text { Passive Design } \\
\text { Toolkit }\end{array}$ \\
\hline Orientation & Climatic Considerations & Use of Mechanical Systems & Passive Solar Power \\
\hline Building Shape (Massing) & $\begin{array}{c}\text { Passive Cooling and } \\
\text { Ventilation }\end{array}$ & South-Facing Glass & Orientation. \\
\hline Choice of Materials & Passive Heating & Thermal Mass & Interior Layout \\
\hline $\begin{array}{l}\text { Landscaping (Heat Island } \\
\text { Effect) }\end{array}$ & $\begin{array}{c}\text { Lighting Controls and } \\
\text { Dayligting }\end{array}$ & Orientation & Insulation \\
\hline $\begin{array}{l}\text { Water bodies and vegetation } \\
\text { (Micro-climate) }\end{array}$ & Passive Water Strategies & $\begin{array}{c}\text { Site Planning for Solar } \\
\text { Access }\end{array}$ & Windows (glazing) \\
\hline Daylighting & & Space Planning & Lighting \\
\hline Space Conditioning & & & Ventilation \\
\hline Passive Cooling & & & Thermal mass \\
\hline Preventive Techniques & & & \\
\hline Natural Ventilation & & & \\
\hline Radiative & & & \\
\hline Evaporative & & & \\
\hline Earth Coupling & & & \\
\hline Passive Heating & & & \\
\hline
\end{tabular}

This study aims to analyze single-story houses in residential areas of Al-Bayda - Libya, in terms of orientation, shadow areas, natural ventilation, and site plan decisions; essential criteria of passive system design, and also to put forward positive and negative design decisions on selected examples. Thus, within the framework of the analysis criteria discussed, it is aimed to make suggestions for future architectural layouts to increase energy efficiency.

\section{METHODOLOGY}

The study was carried out in three main phases. The first phase included a literature review to identify the energy efficiency of the principles of a residential building to be utilized. The second phase includes fieldwork consisting of the site visit and examination of eight buildings. During the site visits, interviews were also done with users of the selected buildings. In the third stage, the information gathered was analyzed, results were discussed, and recommendations were made.

\subsection{Study area}

The city of Al-Bayda is in the northeast of Libya (Figure 1). It is the highest peak of the Green Mountain, located at the latitude 21.44 North and the longitude 32.76 east [12]. It is bordered to the east by the city of Qurena, to the west by the village of Massa, to the south of Aslanta, and the north by the intermediate forests, making it the middle of the green mountain.

The wet winter and the hot, dry summers characterize Libya's climate, and the arid climate is evident in the transition from the Mediterranean to the stormy climate.

Due to the mediation of the city's location between the governors of Darnah, Marj, Qubba, and Benghazi, its location in the middle of Al-Jabal Al-Akhdar has become an urban complex of commercial nature and a shopping center for its neighboring towns and villages. It is close to the sea by $20 \mathrm{~km}$ and surrounded by forests.

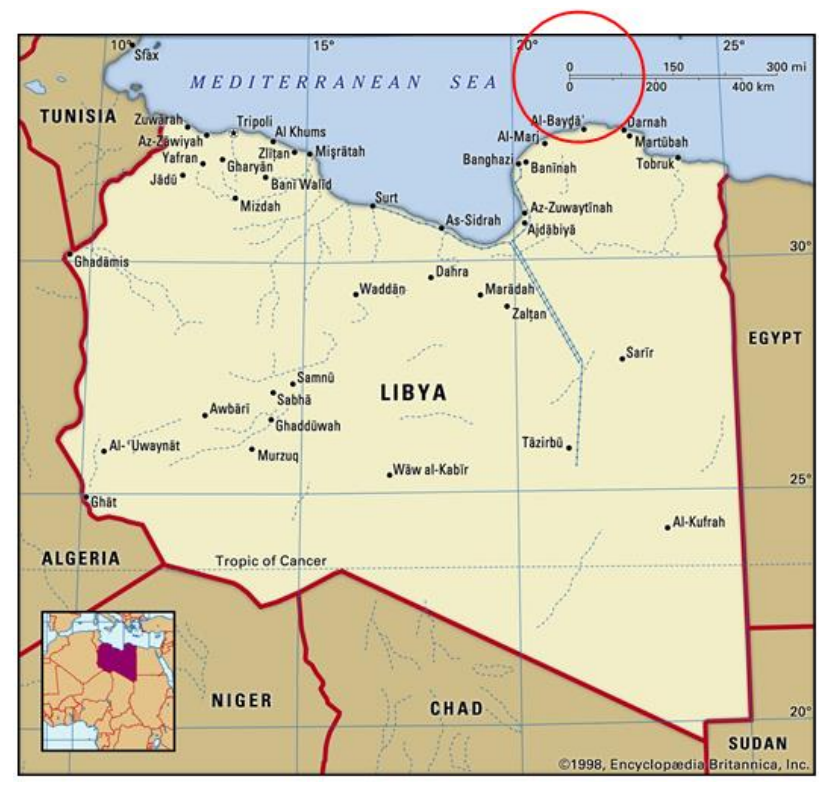

Figure 1. Map showing the location of the city of Al Bayda, Libya [13]

Summer is long, warm, arid, and clear; winter is cool, windy, and often clear. The temperature typically varies from year to year from $42^{\circ}$ Fahrenheit to $83^{\circ}$ Fahrenheit; it rarely falls below $38^{\circ}$ Fahrenheit or rises above $93^{\circ}$ Fahrenheit [14] The hot season is average above $78^{\circ}$ Fahrenheit a day between May 23 and October 9. The hottest day of the year on August 8 is $83^{\circ}$ Fahrenheit and $67^{\circ}$ Fahrenheit on average. The cold period between 5 th and 12 th December is below $61^{\circ}$ Fahrenheit with a mean daily high temperature. The coldest day of the year is the month of February 1, with an average of 42 and 55 degrees (Figure 2). The daily average temperature is indicated in Figure 3.

The maximum expected wind speeds are around $46 \mathrm{~km} / \mathrm{h}$ but the average air speed is generally between 17 and $29 \mathrm{~km} / \mathrm{h}$. Furthermore, as shown in Figures 4, 5 (Annual wind performance by Autodesk Revit, 2016) the main wind flow comes from the north. 


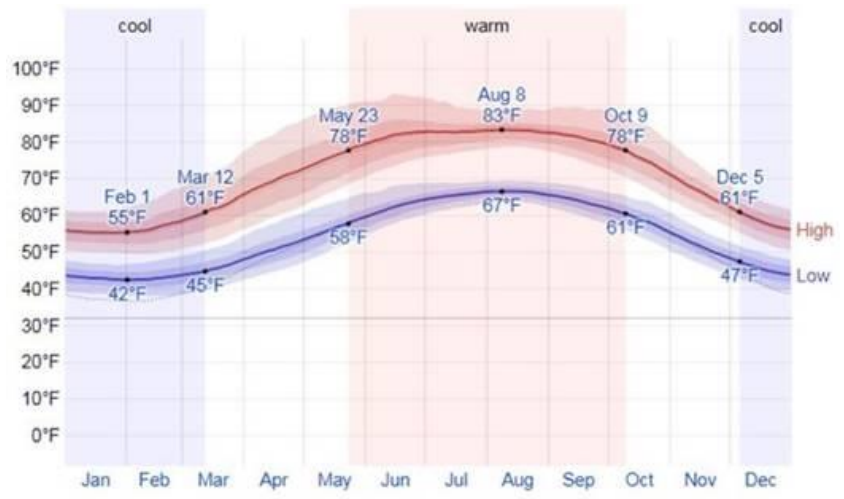

Figure 2. Average high and low temperature [14]

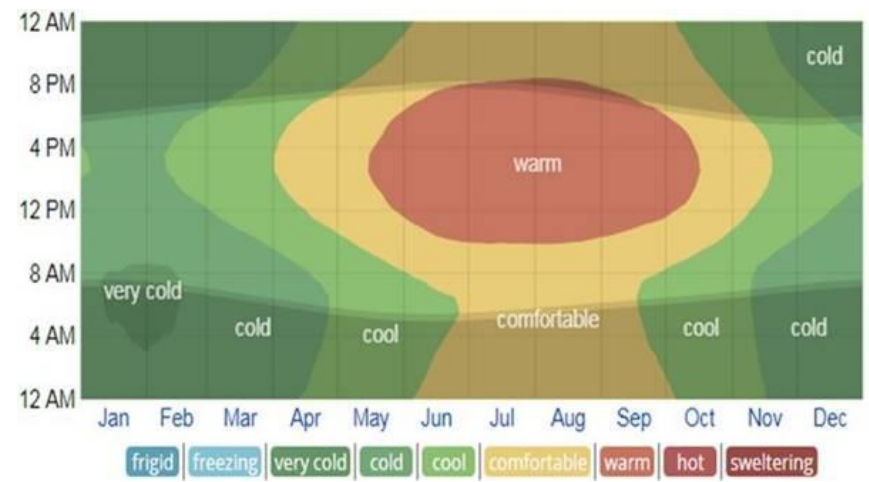

Figure 3. Hourly temperature average [14]

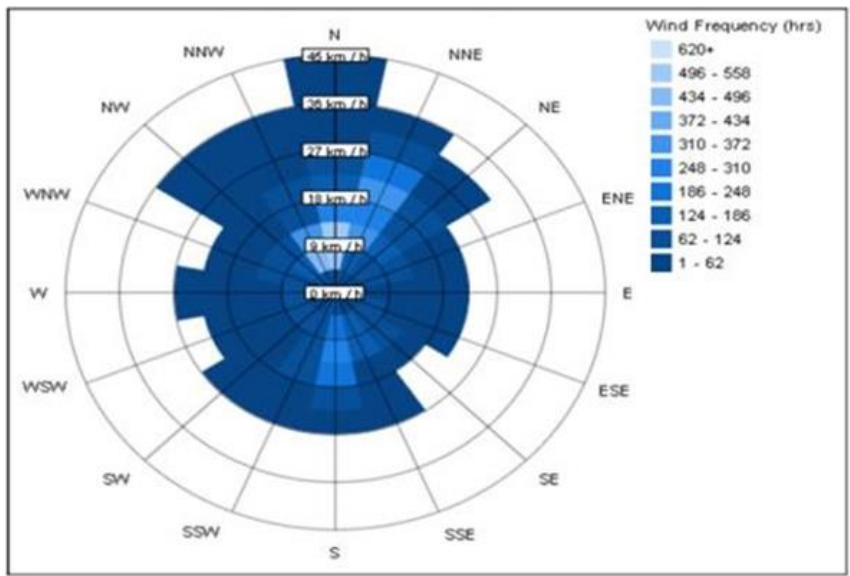

Figure 4. Annual wind rose (Frequency distribution)

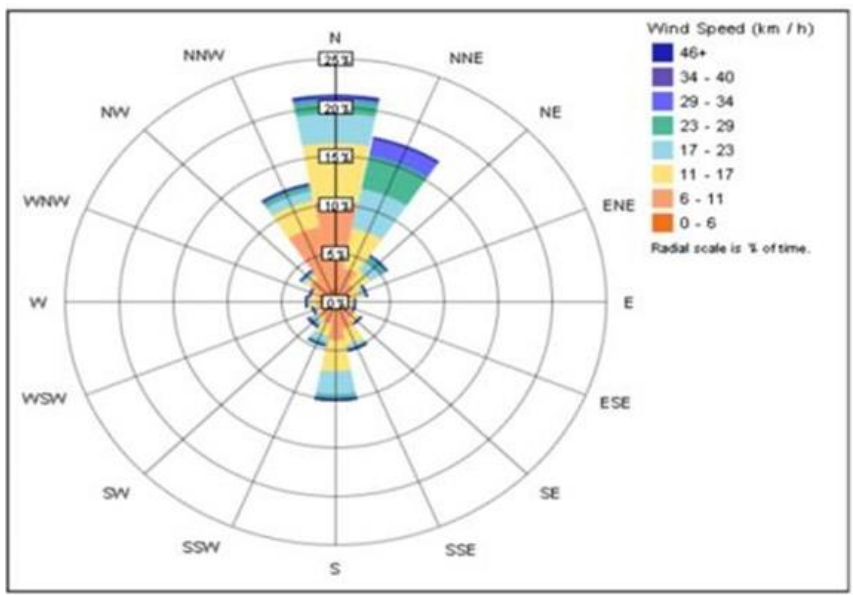

Figure 5. Annual wind rose (Speed distribution)

\section{CASE STUDY: SHADING AND AIR FLOW ANALYSIS ON SELECTED RESIDENTIAL BUILDINGS IN AL - BAYDA CITY}

This study demonstrates the analysis of energy efficiency strategies in residential buildings in the Al - Bayda City, Libya. Research and findings of eight houses selected randomly in Downtown city in Al-Bayda were discussed in terms of orientation, solar energy gain in the summer and winter solstice, and winds' effect on natural ventilation. The study includes a range of buildings in terms of orientation, energy efficiency, and the impact of solar radiation on buildings simulating by a computer program (Autodesk Revit 2016). An interview was also done with the owners of the houses selected for the study, and the results were evaluated. A framework was developed for shading and air movement analysis of the buildings. The framework was divided into three essential parts. In the first part, general information about building location, plans, sections, elevations, sizes, materials, etc., are mentioned. In the second part, shading analysis (using Autodesk Revit) and airflow analysis of buildings were done on a theoretical basis. In this part, the user's response to solar and ventilation effects is also reflected. In this way, the compatibility relation between analysis and user's responses could also be seen. The third part of the framework was used to evaluate the shading and air movement facilities of the building. An interview was conducted with the residents of the selected houses as well. Seventeen questions were asked to the users. Questions from one to eight determines the buildings' physical properties together with the used mechanical devices and measures the awareness of users on energy conservation. Questions from nine to seventeen determines thermal comfort in spaces and satisfaction on use of natural ventilation and radiation control at their homes. Questions are as follows:

1. Do you have heat insulation on walls?

2. Do you have heat insulation on glazing?

3 . What kind of construction system is used in your building?

4. What are the cooling devices used in the home?

5 . What kind of heating is used in the home?

6. How much do you pay monthly for electricity ranges?

7. How can you estimate the energy consumption in your home?

8. Do you know that energy consumption is harmful to the environment?

9. How often do you use natural ventilation in summer?

10. How often do you use mechanical ventilation in summer?

11. How often solar radiation reaches the bedrooms?

12. How often solar radiation reaches into the living room?

13. What are the shading devices available in your home?

14. How do you grade level of satisfaction in terms of ventilation in your home?

15. How do you grade level of satisfaction in gaining sun's energy in your home?

16. Is there a difference in the thermal comfort between rooms in your home?

17. According to you, are buildings adjacent to the building prevent the winds into the house?

The answers were expected to provide mainly how much user's are satisfied with the natural means for thermal comfort purposes. The answers also gave information about kind of tools or devices used by users for obtaining thermal comfort in their spaces.

At the end of the study, the responses of the building users were compared with the buildings airflow and shade analysis 
results. Similarities of the results were checked.

\section{SURVEY RESULTS}

The results of the interview of respondents from the owners of houses are as follows:

The age of the respondents was $30-40,37.5 \%, 41-50,25 \%$, $51-60,25 \%$ and respondents aged more than 60 were the lowest as $12.5 \%$ (Table 2).

Table 2. The age distribution of the respondents

\begin{tabular}{cccc}
\hline & Frequency & $\begin{array}{c}\text { Valid } \\
\text { Percent }\end{array}$ & $\begin{array}{c}\text { Cumulative } \\
\text { Percent }\end{array}$ \\
\hline $30-40$ & 3 & 37.5 & 37.5 \\
$41-50$ & 2 & 25.0 & 62.5 \\
$51-60$ & 2 & 25.0 & 87.5 \\
More than & 1 & 12.5 & 100.0 \\
60 & & & \\
Total & 8 & 100.0 & \\
\hline
\end{tabular}

According to Table 3, 100\% of the respondents have said that there was no heat insulation on the walls.

Table 3. Heat insulation on walls

\begin{tabular}{ccccc}
\hline & & Frequency & Valid Percent & Cumulative Percent \\
\hline Valid & No & 8 & 100.0 & 100.0 \\
\hline
\end{tabular}

In Table $4,87.5 \%$ of the respondents agreed (Houses $2,3,4,5,6,7,8,9)$ that there was no heat insulation on the glazing.

Table 4. Heat insulation on glazing

\begin{tabular}{ccccc}
\hline & Frequency & Valid Percent & $\begin{array}{c}\text { Cumulative } \\
\text { Percent }\end{array}$ \\
\hline Valid & No & 7 & 87.5 & 87.5 \\
& Yes & 1 & 12.5 & {$[0.0$} \\
& Total & 8 & 100.0 & \\
\hline
\end{tabular}

In Table 5, 75\% of the respondents agreed that the construction systems used in the buildings are frame system and the remaining percentage, $25 \%$ agreed for load bearing system.

Table 5. The construction system

\begin{tabular}{|c|c|c|c|c|}
\hline & & Frequency & $\begin{array}{c}\text { Valid } \\
\text { Percent }\end{array}$ & $\begin{array}{c}\text { Cumulative } \\
\text { Percent }\end{array}$ \\
\hline \multirow[t]{3}{*}{ Valid } & $\begin{array}{c}\text { Load bearing } \\
\text { system }\end{array}$ & 2 & 25.0 & 25.0 \\
\hline & Frame system & 6 & 75.0 & 100.0 \\
\hline & Total & 8 & 100.0 & \\
\hline
\end{tabular}

Another question was about the cooling devices which are used in the houses. Two main types of air conditioning were mentioned in the survey as AC units and fans. The results reveal that air conditioning units were widespread, with $75 \%$ and with the percentage $25 \%$ fans were used for cooling purposes (Table 6).
Table 6. Cooling devices used in houses

\begin{tabular}{ccccc}
\hline & & Frequency Valid Percent & $\begin{array}{c}\text { Cumulative } \\
\text { Percent }\end{array}$ \\
\hline Valid & Air conditioning & 6 & 75.0 & 75.0 \\
& Fans & 2 & 25.0 & 100.0 \\
& Total & 8 & 100.0 & \\
\hline
\end{tabular}

According to the results about the heating devices used in the houses; it was founded that in the $75 \%$ of the houses electric heaters were used, and in $25 \%$ air conditioning units (Table 7).

Table 7. Heating devices used in houses

\begin{tabular}{ccccc}
\hline & & $\begin{array}{c}\text { Frequenc } \\
\mathbf{y}\end{array}$ & $\begin{array}{c}\text { Valid } \\
\text { Percent }\end{array}$ & $\begin{array}{c}\text { Cumulative } \\
\text { Percent }\end{array}$ \\
\hline Valid & Electric heater & 6 & 75.0 & 75.0 \\
& Air conditioning & 2 & 25.0 & 100.0 \\
& Total & 8 & 100.0 & \\
\hline
\end{tabular}

Table 8 shows the monthly payments for electricity in the houses. Highest percentage with $50 \%$, the residents pay 250 $300 \$$ monthly, $30 \%$ of the users $150-200 \$, 10 \%$ 200-250 $\$$ and $10 \%$ pay less than $50 \$$.

Table 8. The monthly payment for electricity

\begin{tabular}{cccc}
\hline \multicolumn{4}{c}{ Frequency Valid Percent Cum. Percent } \\
\hline Valid Less than $50 \$$ & 1 & 12.5 & 12.5 \\
$150-200 \$$ & 2 & 25.0 & 37.5 \\
$200-250 \$$ & 1 & 12.5 & 50.0 \\
$250-300 \$$ & 4 & 50.0 & 100.0 \\
Total & 8 & 100.0 & \\
\hline
\end{tabular}

Table 9 shows the results of the survey about estimated energy consumptions. The results revealed that $62.5 \%$ of the houses has a high-cost and $37.5 \%$ have average cost.

Table 9. Estimated the energy consumption

\begin{tabular}{|c|c|c|c|}
\hline \multirow[b]{2}{*}{ Valid } & \multicolumn{3}{|c|}{ Frequency Valid Percent Cumulative Percent } \\
\hline & 3 & 37.5 & 37.5 \\
\hline High-cost & 5 & 62.5 & 100.0 \\
\hline Total & 8 & 100.0 & \\
\hline
\end{tabular}

In Table 10, the respondents' awareness about the environmental damage caused by energy consumption can be seen. The survey revealed that $100 \%$ of the respondents were not aware of the damage caused by energy consumption.

Table 10. Awareness of the respondents about energy consumption and its harmful effect to the environment

\begin{tabular}{lccc}
\hline \multicolumn{3}{r}{ Frequency Valid Percent Cumulative Percent } \\
\hline Valid No & 8 & 100.0 & 100.0 \\
\hline
\end{tabular}

Table 11 indicates the results about the use of natural ventilation in summer. According to the results, $50 \%$ of the respondents use natural ventilation opportunities sometimes, and $50 \%$ use natural ventilation opportunities very often. 
Table 11. The use of the natural ventilation in summer

\begin{tabular}{ccccc}
\hline & Frequency & $\begin{array}{c}\text { Valid } \\
\text { Percent }\end{array}$ & $\begin{array}{c}\text { Cumulative } \\
\text { Percent }\end{array}$ \\
\hline Valid & $\begin{array}{c}\text { Sometimes } \\
\text { Most of the } \\
\text { time }\end{array}$ & 4 & 50.0 & 50.0 \\
& 4 & 50.0 & 100.0 \\
Total & 8 & 100.0 & \\
\hline
\end{tabular}

Another question was about people's behavior regarding the use of mechanical ventilation in summer. According to Table $12,75 \%$ of the respondents, which is the highest percentage, mentioned that they frequently use mechanical ventilation, and $12.5 \%$ said they did not use mechanical ventilation.

Table 12. Use of mechanical ventilation in summer

\begin{tabular}{ccccc}
\hline & & Frequency & $\begin{array}{c}\text { Valid } \\
\text { Percent }\end{array}$ & $\begin{array}{c}\text { Cumulative } \\
\text { Percent }\end{array}$ \\
\hline Valid & Never & 1 & 12.5 & 12.5 \\
& $\begin{array}{c}\text { Sometimes } \\
\text { Most of the } \\
\text { time }\end{array}$ & 1 & 12.5 & 25.0 \\
& 6 & 75.0 & 100.0 \\
& Total & 8 & 100.0 & \\
\hline
\end{tabular}

Table 13 shows how frequent the solar radiation enters to the bedrooms. According to the results, $50 \%$ of the respondents said sometimes, $25 \%$, rarely, and $25 \%$ most of the time.

Table 13. The solar radiation entering the bedrooms

\begin{tabular}{ccccc}
\hline & Frequency & $\begin{array}{c}\text { Valid } \\
\text { Percent }\end{array}$ & $\begin{array}{c}\text { Cumulative } \\
\text { Percent }\end{array}$ \\
\hline Valid & Rarely & 2 & 25.0 & 25.0 \\
& Sometimes & 4 & 50.0 & 75.0 \\
& $\begin{array}{c}\text { Most of the } \\
\text { time }\end{array}$ & 2 & 25.0 & 100.0 \\
& Total & 8 & 100.0 & \\
\hline
\end{tabular}

The results in Table 14 is about how often solar radiation enters the living room. The results showed that, $25 \%$ of the respondents said "sometimes", $37.5 \%$ said "rarely", $12.5 \%$ said "never" and 25\% said "most of the time".

Table 14. The solar radiation entering the living room

\begin{tabular}{ccccc}
\hline & & Frequency & $\begin{array}{c}\text { Valid } \\
\text { Percent }\end{array}$ & $\begin{array}{c}\text { Cumulative } \\
\text { Percent }\end{array}$ \\
\hline Valid & Never & 1 & 12.5 & 12.5 \\
& Rarely & 3 & 37.5 & 50.0 \\
& Sometimes & 2 & 25.0 & 75.0 \\
& Most of the & 2 & 25.0 & 100.0 \\
& time & 8 & 100.0 & \\
\hline & Total & 8 & & \\
\hline
\end{tabular}

In Table 15, 37.5\% of the respondents agreed that no shading devices are available in their houses and $62.5 \%$ use the curtains.

Table 16 shows the results of the survey about the level of satisfaction in terms of ventilation. According to the results, $37.5 \%$ of the respondents' satisfaction level was poor, $25 \%$ good, $12.5 \%$ Very good, and $25 \%$ very poor.
Table 15. The shading devices available in the home

\begin{tabular}{cccc}
\hline & Frequency & Valid Percent & Cumulative Percent \\
\hline Valid Curtains & 5 & 62.5 & 62.5 \\
Nothing & 3 & 37.5 & 100.0 \\
Total & 8 & 100.0 & \\
\hline
\end{tabular}

Table 16. Level of satisfaction in terms of ventilation

\begin{tabular}{ccccc}
\hline & Frequency & Valid Percent & $\begin{array}{c}\text { Cumulative } \\
\text { Percent }\end{array}$ \\
\hline Valid & Very poor & 2 & 25.0 & 25.0 \\
& Poor & 3 & 37.5 & 62.5 \\
Good & 2 & 25.0 & 87.5 \\
Very good & 1 & 12.5 & 100.0 \\
Total & 8 & 100.0 & \\
\hline
\end{tabular}

Table 17 shows the level of satisfaction in terms of gaining the sun's energy in the home.

Table 17. Level of satisfaction in terms of gaining the sun's energy in the home

\begin{tabular}{|c|c|c|c|c|}
\hline & & Frequency & $\begin{array}{c}\text { Valid } \\
\text { Percent }\end{array}$ & $\begin{array}{c}\text { Cumulative } \\
\text { Percent }\end{array}$ \\
\hline \multirow[t]{5}{*}{ Valid } & Very poor & 3 & 37.5 & 37.5 \\
\hline & Poor & 2 & 25.0 & 62.5 \\
\hline & Good & 2 & 25.0 & 87.5 \\
\hline & Very good & 1 & 12.5 & 100.0 \\
\hline & Total & 8 & 100.0 & \\
\hline
\end{tabular}

Table 18 shows the results of the survey about the difference in the thermal comfort between rooms in houses. $62.5 \%$ of the respondents confirmed that there is difference in the thermal comfort between rooms in their houses and $37.5 \%$ mentioned that there was no difference.

Table 18. The difference in thermal comfort between the rooms in houses

\begin{tabular}{cccc}
\hline & Frequency & Valid Percent & Cumulative Percent \\
\hline Valid No & 3 & 37.5 & 37.5 \\
Yes & 5 & 62.5 & 100.0 \\
Total & 8 & 100.0 & \\
\hline
\end{tabular}

In Table 19 the percentages of the houses which can benefit and cannot benefit from the wind because of the adjacent houses is given. According to the results, $50 \%$ of the buildings benefit from the wind, but the rest was not.

Table 19. Prevention of the wind because of the adjacent buildings

\begin{tabular}{ccccc}
\hline & & Frequency & Valid Percent & $\begin{array}{c}\text { Cumulative } \\
\text { Percent }\end{array}$ \\
\hline Valid & No & 4 & 50.0 & 50.0 \\
& Yes & 4 & 50.0 & 100.0 \\
& Total & 8 & 100.0 & \\
\hline
\end{tabular}

A total of eight random buildings was selected in the city of Al-Bayda. Analysis of energy efficient strategies of these residential buildings are done according to the selected criteria. Several buildings, which contribute to high energy 
consumption and cause environmental damage, have been observed. The selected buildings were analyzed in terms of climatic elements that affect the thermal comfort of the building's internal environment. Summer and winter outdoor shading conditions and air movements, indoor and outdoor spaces are examined and criticized (Tables 20-27).

Table 20. Case study 1

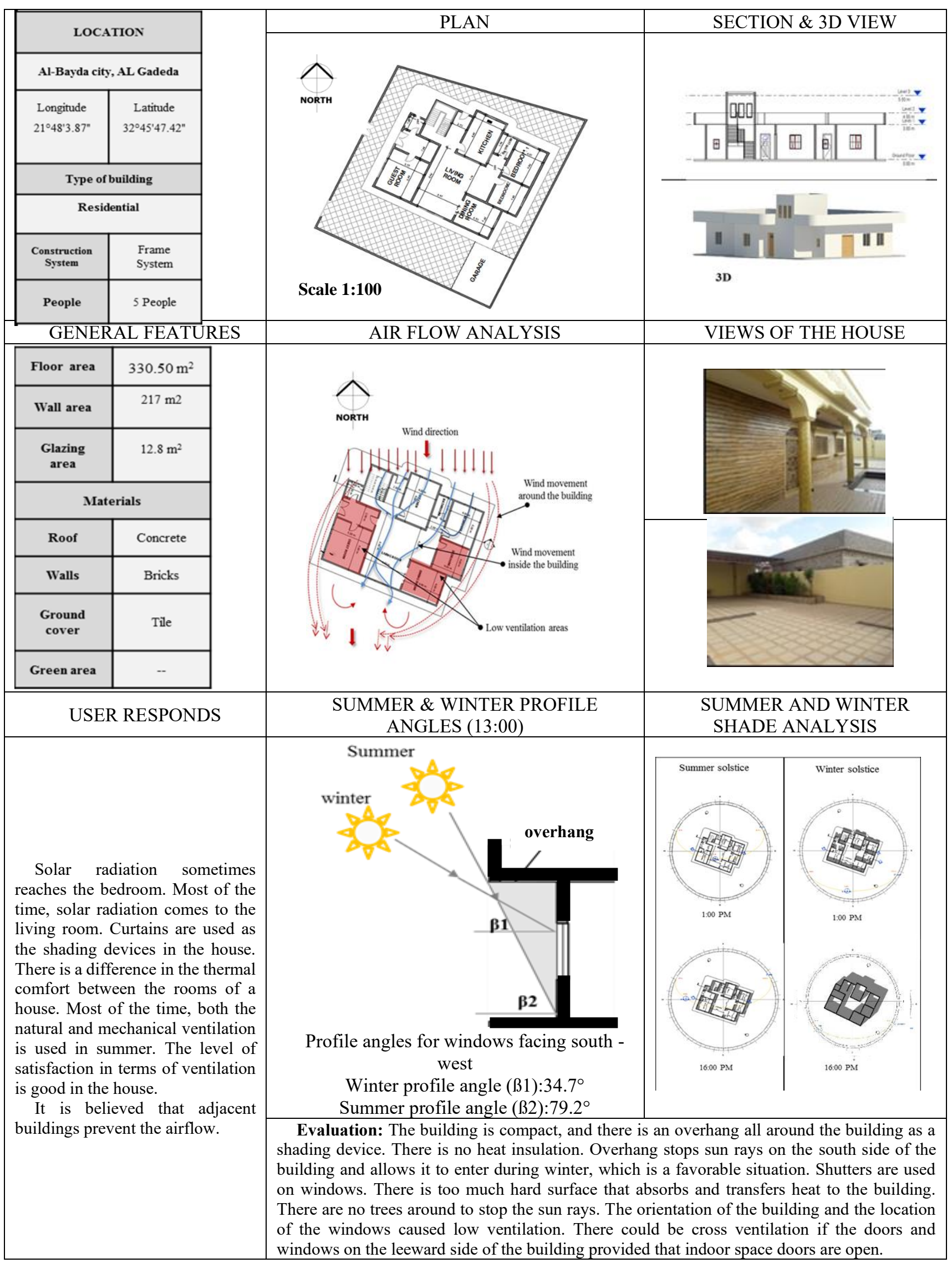


Table 21. Case study 2

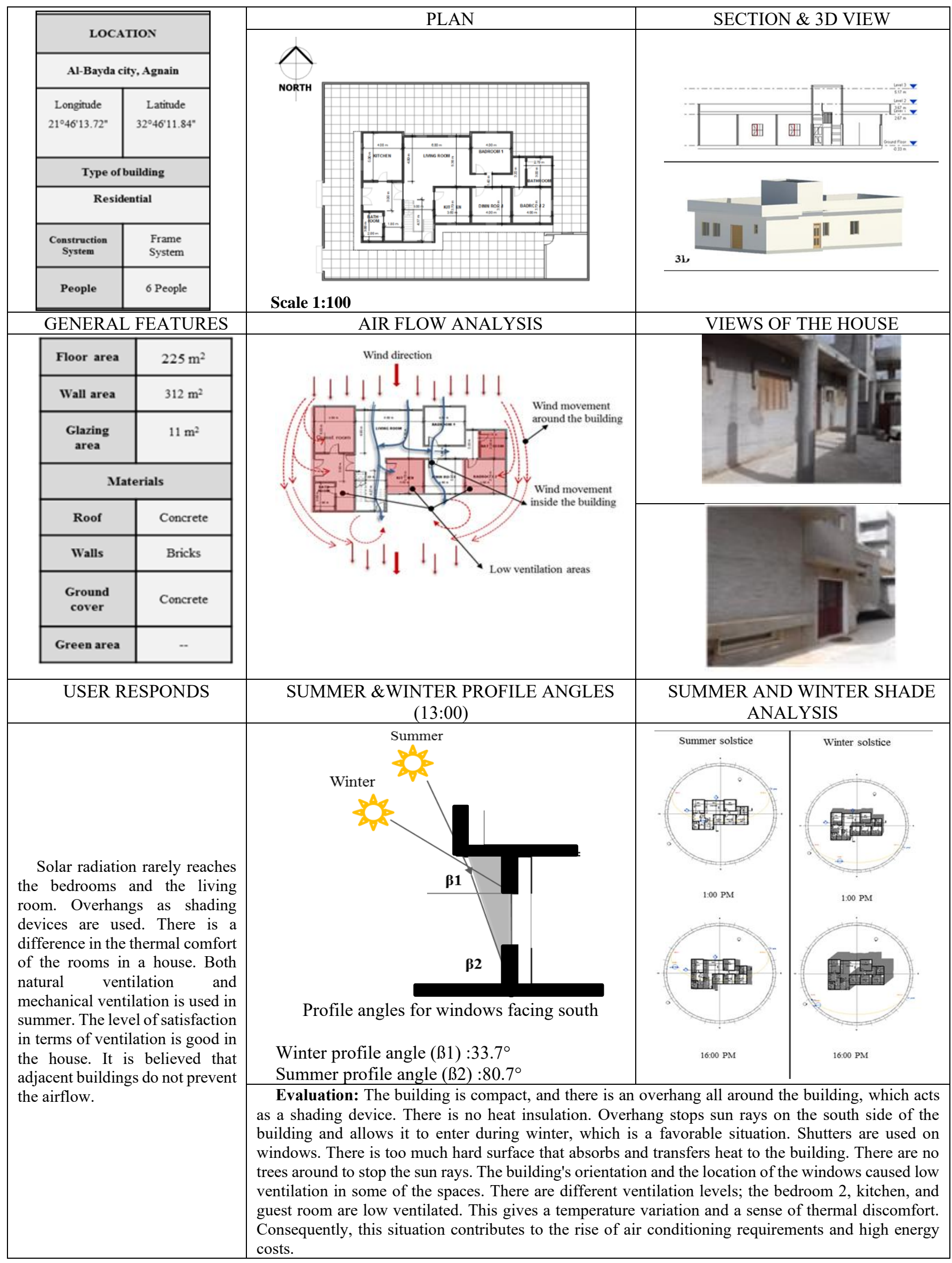


Table 22. Case study 3

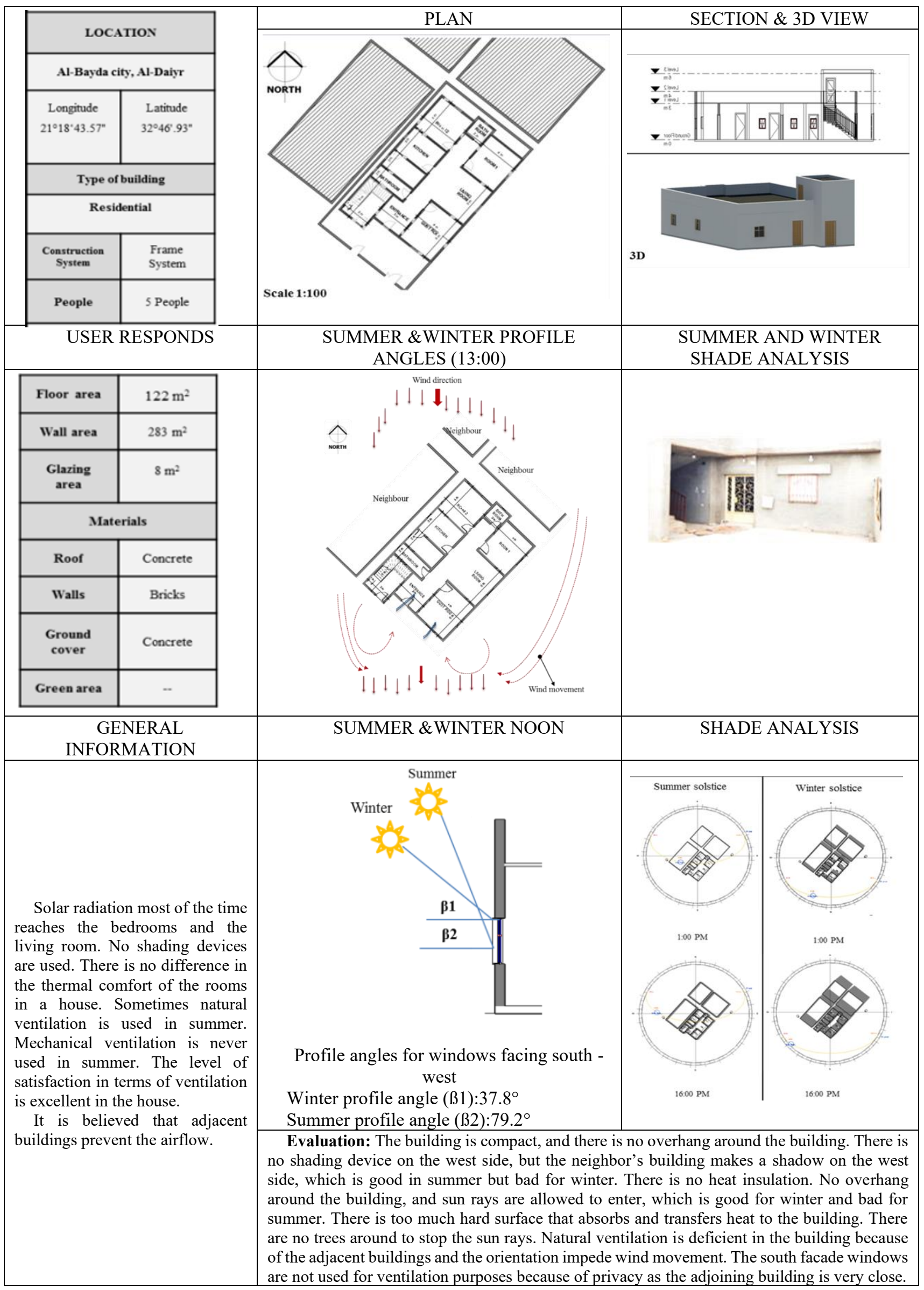


Table 23. Case study 4

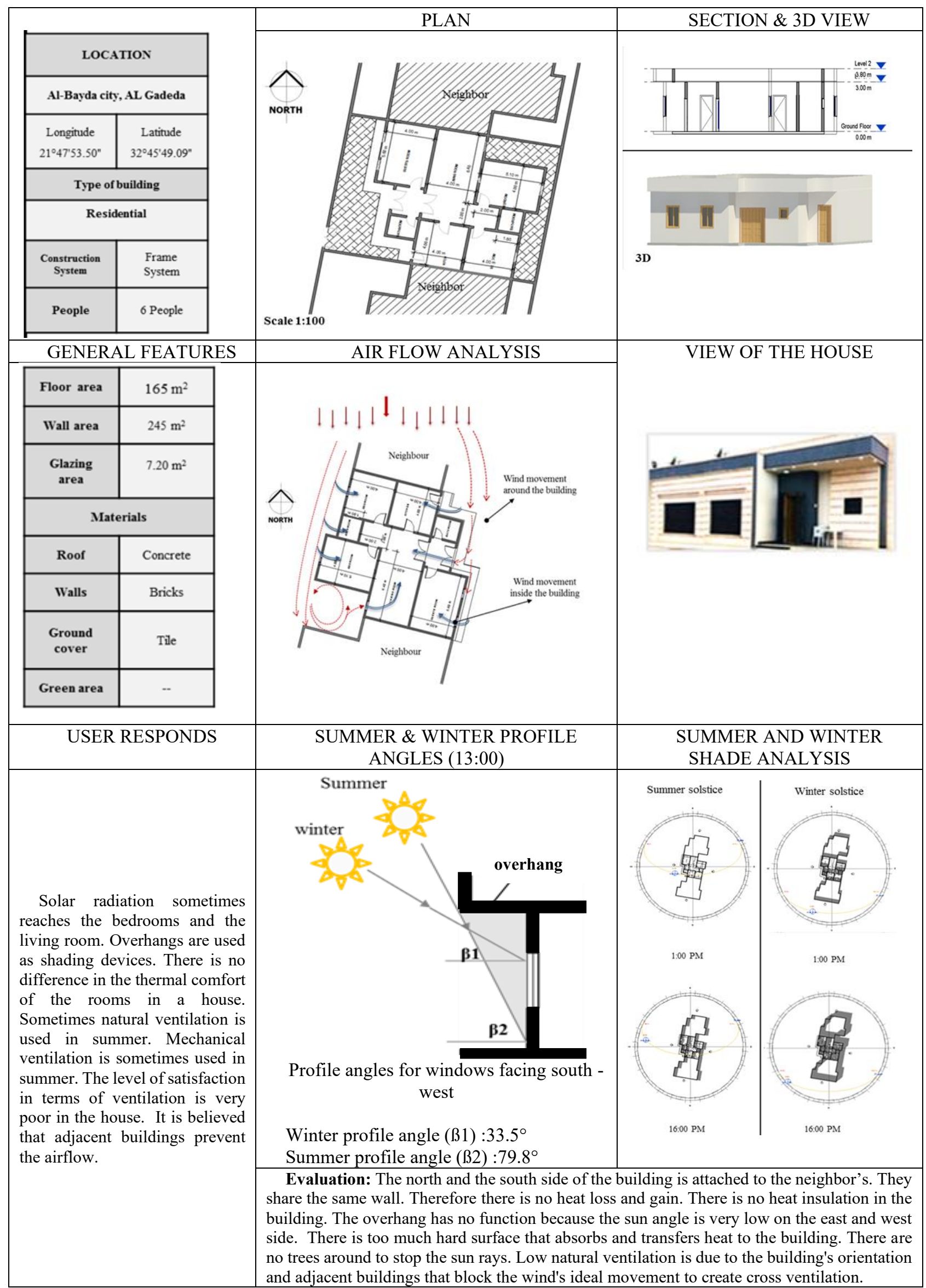


Table 24. Case study 5

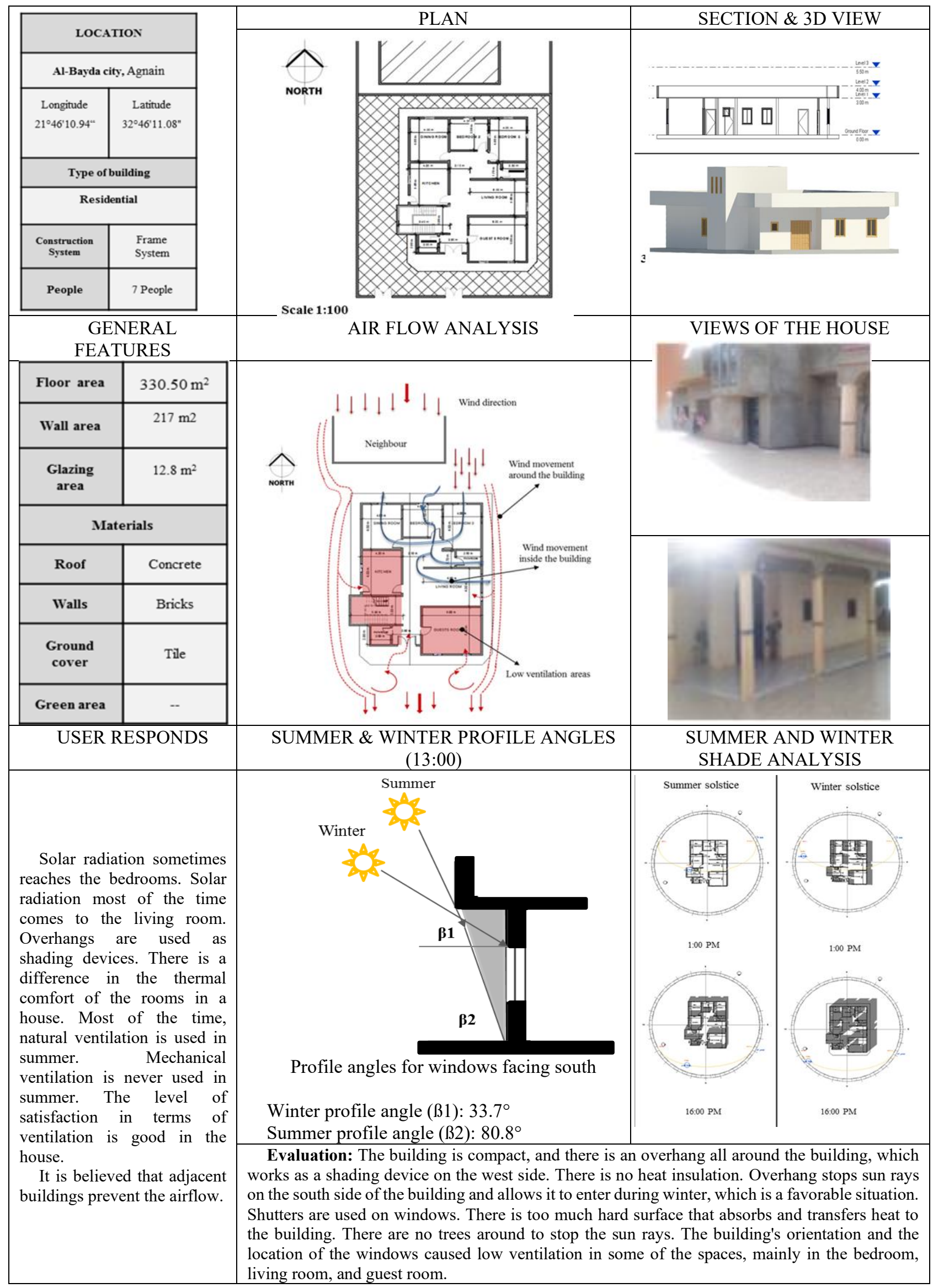


Table 25. Case study 6

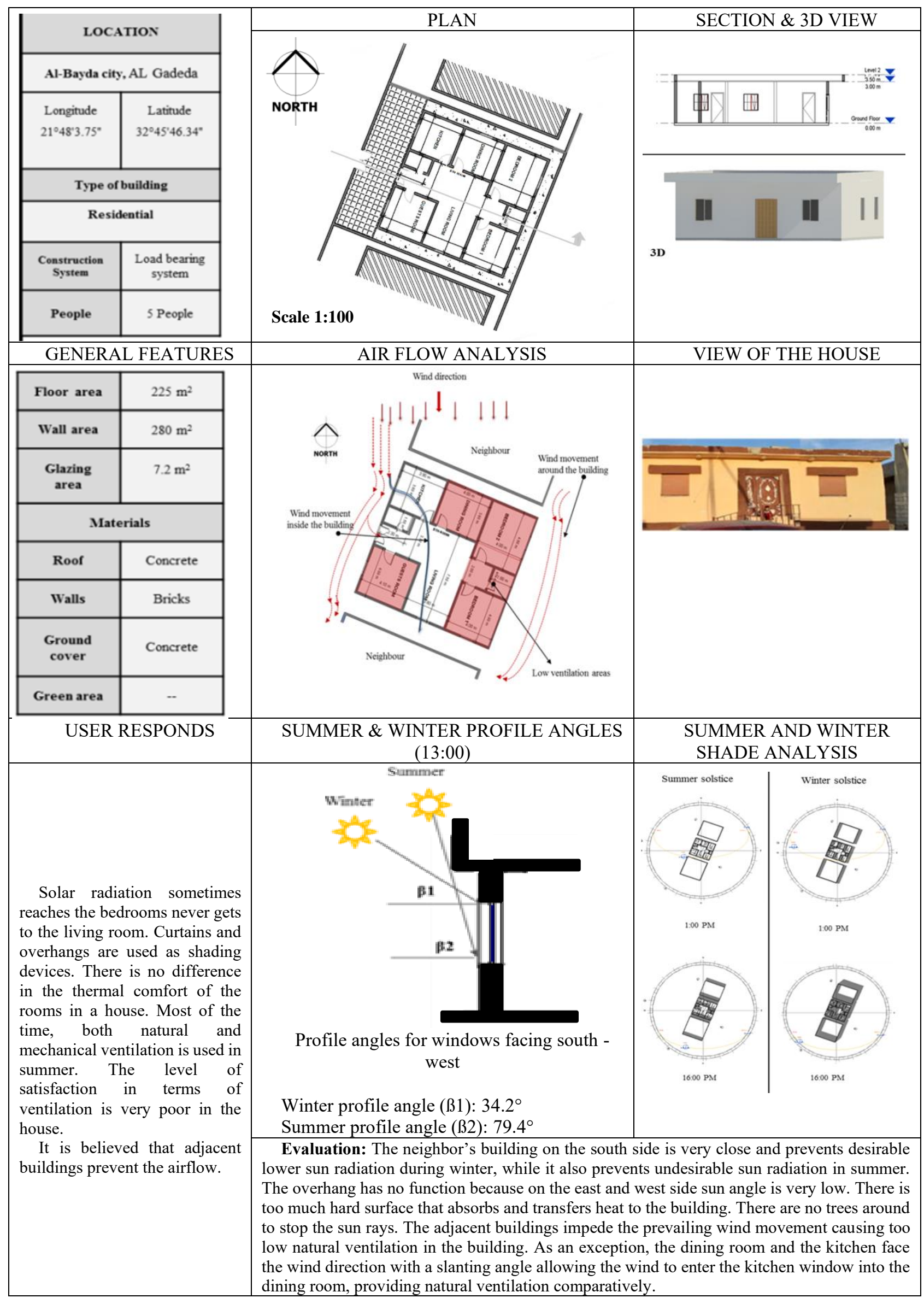


Table 26. Case study 7

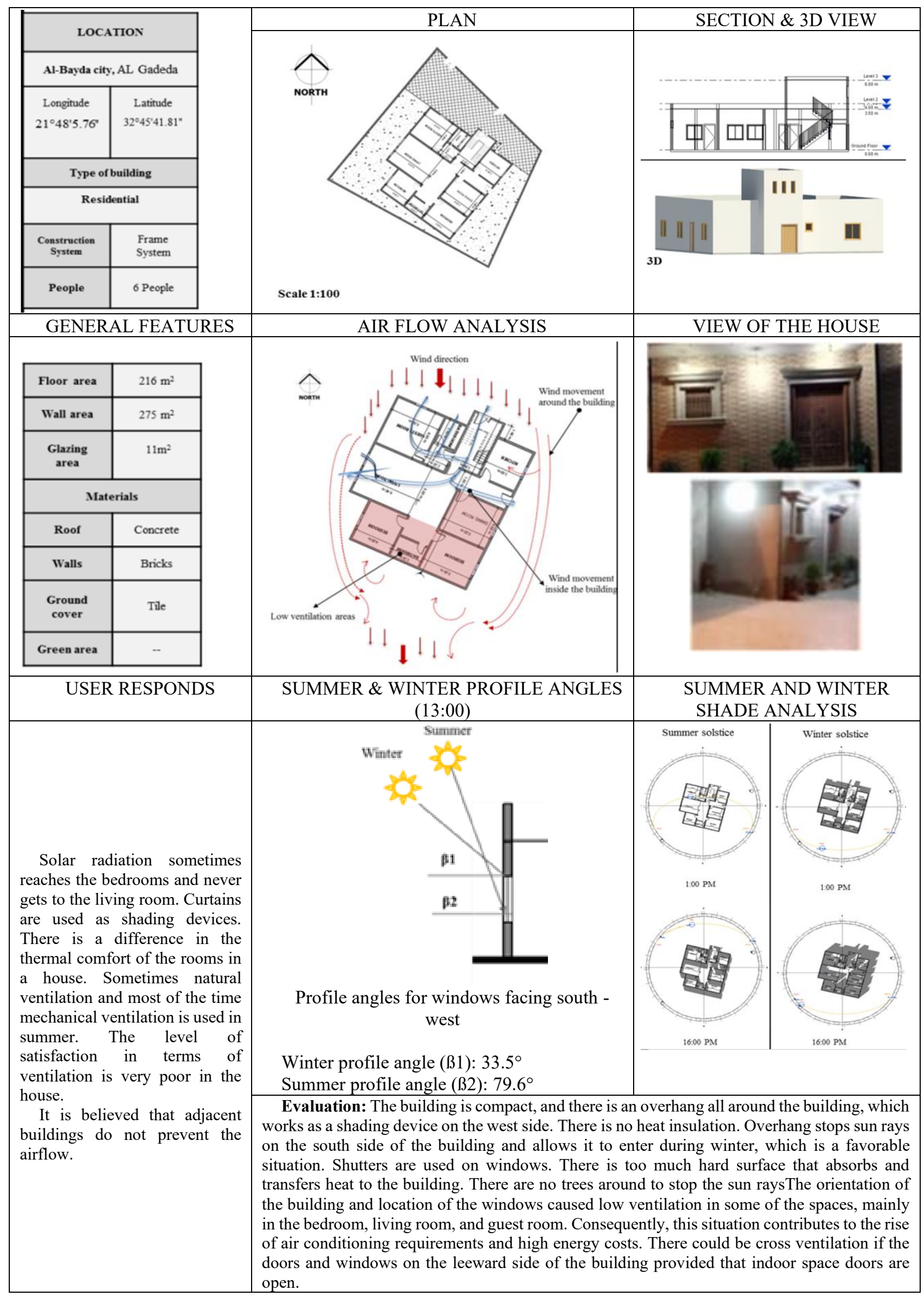


Table 27. Case study 8

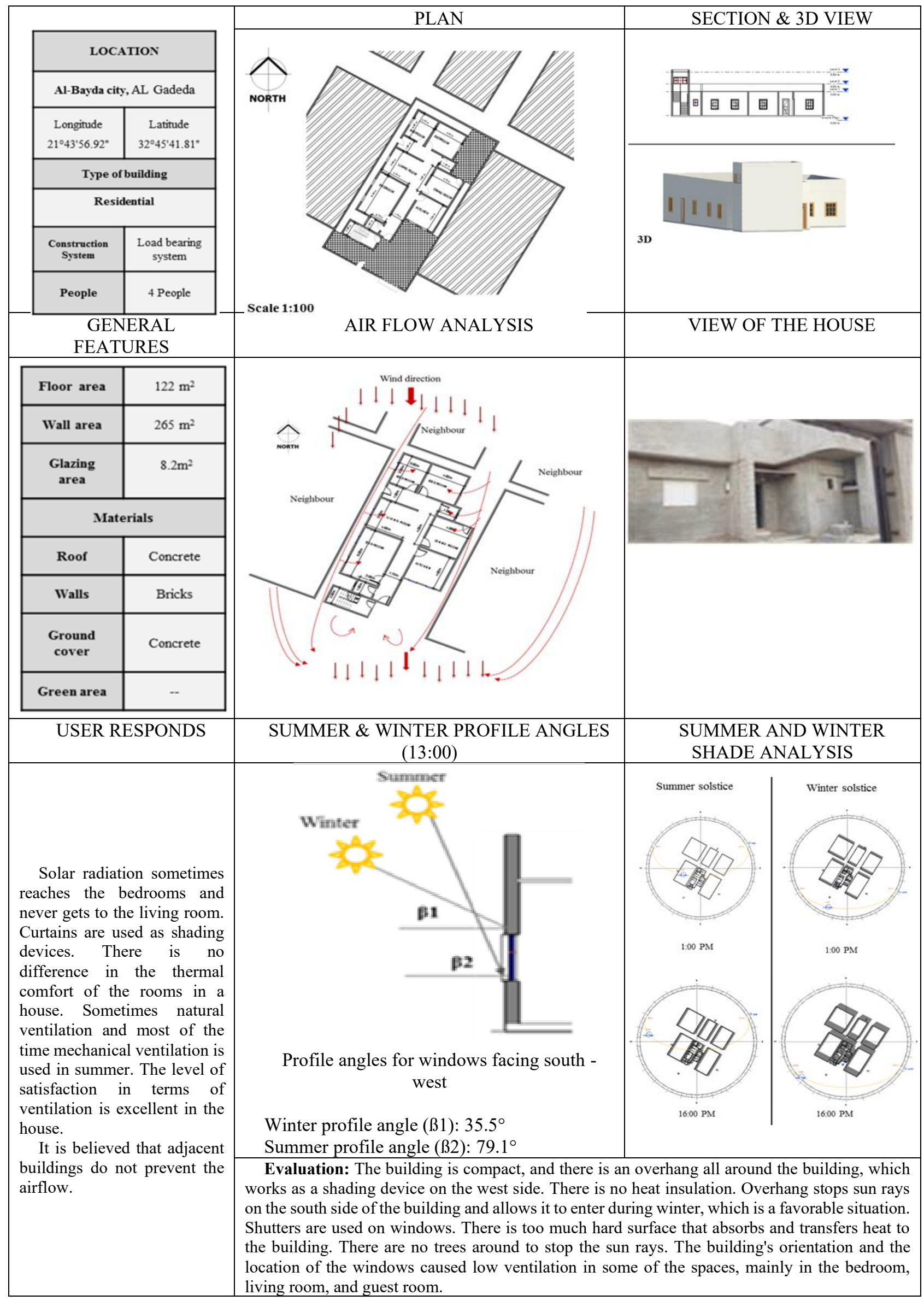




\section{CONCLUSION AND RECOMMENDATIONS}

This study was conducted to analyze the energy efficiency strategies of residential buildings in the city of Al-Bayda. The research discussed climate design principles, which play an essential role in the internal environment quality and energy consumption of residential buildings.

In the interviews, the users demonstrated their satisfaction in thermal comfort when they do not use air conditioning in their living spaces. When the thermal comfort responses of the users are taken into consideration, similar results have been obtained when the possibilities of natural air flows and the effects of radiation due to orientation on the building designs are analyzed on a theoretical basis. This means that providing cross-air currents in the interior, which is one of the passive design strategy criteria, and benefiting or protecting from the principal radiation based on orientation and use of sun shading elements have essential effects on thermal comfort in the architectural design phase.

As mentioned above eight houses in Al-Bayda city were selected and the research results were related with climate analysis based on shading and air movement. Orientation and solar radiation effects are examined through computer simulation (by Autodesk Revit 2016) to determine the suitability of homes with their local environment. The impact on energy consumption can be summarized as follows;

- In summer, buildings are affected by solar radiation in large quantities, and the roof becomes the dominant building element that absorbs radiation and transfers it into the living spaces. Because of this initiates wide use of air - conditioners together and causing high energy costs.
- Inappropriate orientation of buildings are not in harmony with their surroundings and cannot benefit or prevent themselves from climatic factors on the required time of seasons.

- Generally, wind movement is negatively affected by adjacent buildings and causes low natural ventilation.

- Lack of interest in the outer space of the buildings is observed. Plants and/or landscape elements are not used as an architectural tool for solar control and windbreak purposes.

All of these factors have affected houses to pay high energy costs and indirectly increased $\mathrm{CO}_{2}$ emissions. During the interview with the house owners, it has been observed that there is no heat insulation in the walls of their houses. Also, almost no insulation on windows ( $90 \%$ of buildings have no double glazing) is observed. There was also a large consumption of air conditioners ( $80 \%)$. The highest monthly bill cost for electricity consumption was found $\$ 250-\$ 300$. On the other hand, $100 \%$ of respondents were unaware that the environmental damage was caused by energy consumption. In Table 28, general recommendations were expressed on the studied buildings.

The Table 28 was organized so that existing negative situations of buildings, in terms of solar radiation and natural air movement behavior, were reflected with recommended positive architectural sections. One of the research's essential outcomes was that for the city of Al - Bayda, architects could consider the location of living rooms and outdoor terraces on the south-east corner of the buildings where shaded area and the desirable wind is available. It is also recommended to use thermal insulation for buildings and exploit outer space with plants and water bodies.

Table 28. According to "Passive Design Principles" Existing situations and recommendations for the studied buildings

\begin{tabular}{c|c}
\hline Passive Design Principle \\
for Sun and Wind Usage
\end{tabular}

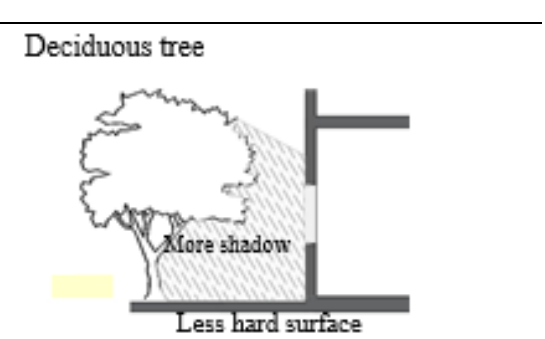

Deciduous trees on the south and south-west site increase shadow area during summer, which allows sun's radiation during winter

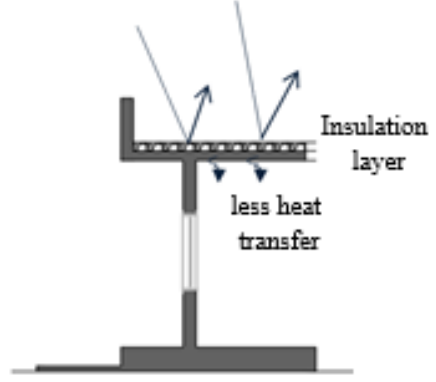

A flat roof can be insulated with several methods of earth, gravel fill may be the cheapest and effective way of obtaining heat insulation. 


\section{3}

Providing cross-ventilation by designing optimum wall openings (door-window)

4

Providing the top vents (windows) for ensuring the heated air going outside

\section{5}

Integrating appropriate shading elements to the building design such as overhangs

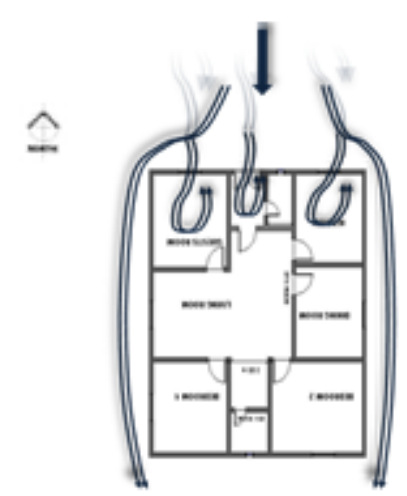

No cross-ventilation

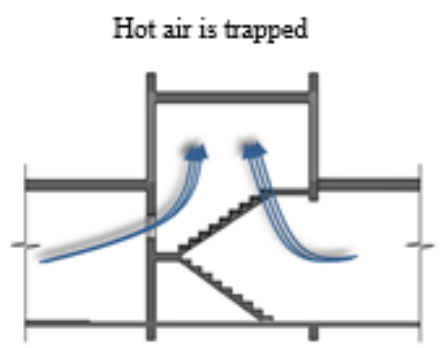

Stagnant hot air
6

Correct orientation of the space during the pre design phase

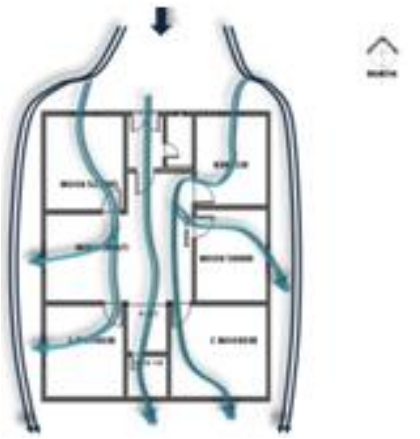

Cross-ventilation can be created through indoor spaces by introducing openings over the internal doors.

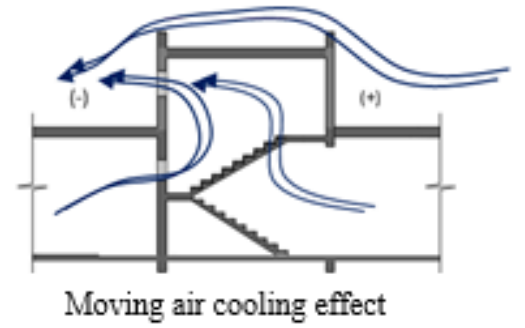

An opening or mechanical fan at the top of staircase can exhaust dirty air outside, while stacking relatively cool air. Thus convective air movement will create a cooling effect.

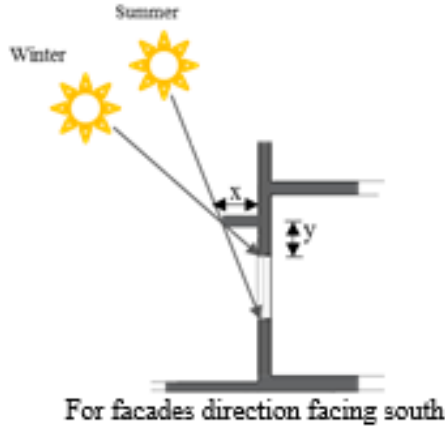

The slab prevents solar radiation in the summer and allows to through in the winter.

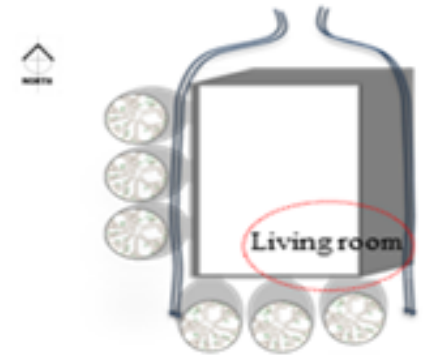

Area for living rooms, outdoor terraces can be located on the south-east corner of the building where shaded area and the desirable wind is available.
According to the comparison between the analysis based on airflow and shade analysis and user survey responses, if the designers consider six simple basic passive design principles during the pre-planning stage, they may provide climatic improvement in sun and wind control in the houses of AlBayda city. These principles are;

1. Adding natural shading elements to the design

2. Adding insulation materials to the building

3.Providing cross-ventilation by designing optimum wall opening (door-window)

4. Designing the top holes (windows) for ensures that the heated air going outside
5. Integrating appropriate shading elements to the building design, such as overhangs

6. Correct orientation of the space during the design phase

Some simple passive design principles that the architects will consider during the design phase will enable people to live more comfortably in buildings. After the evaluation of these results, Architects must be well educated with seminars about climate - responsive building design. The Chamber of architects must encourage life-long learning seminars on climatic design. it can be advised that there should be an awareness campaign for the population about the harms of excess energy consumption. 


\section{REFERENCES}

[1] Rodriguez Ubinas, E., Montero, C., Porteros, M., Vega, S., Navarro, I., Castillo-Cagigal, M., Matallanas, E., Gutiérrez, A. (2014). Passive design strategies and performance of Net Energy Plus Houses. Energy and Buildings, 83:

$10-22$. https://doi.org/10.1016/j.enbuild.2014.03.074

[2] Djamila, H. (2017). Passive strategies of naturally ventilated residential houses in the equatorial humid tropics. International Journal of Environmental Science and Development, 8(2): 102-106. https://doi.org/10.18178/ijesd.2017.8.2.929

[3] Altan, H., Hajibandeh, M., Aoul, K.A.T., Deep, A. (2016). "PassiveDesign," ZEMCH: Toward the Delivery of Zero Energy Mass Custom Homes, Springer, Cham., 209-236. https://doi.org/10.1007/978-3-319-31967-4 8

[4] California Sustainability Alliance. (2016). Passive design handbook https://sustainca.org/sites/default/files/publications/Pass ive_Design_Guidebook_Designed_2015-12-31_0.pdf, accessed on Jan. 20, 2021.

[5] Passive design http://www.esru.strath.ac.uk/EandE/Web sites/0910/Hybrid systems/passivedesign.pdf, accessed on Jan. 25, 2021.

[6] Whang, S.W., Kim, S. (2014). Determining sustainable design management using passive design elements for a zero emission house during the schematic design. Energy and Buildings, 77: 304-312. https://doi.org/10.1016/j.enbuild.2014.03.066

[7] Cruz, A.S., de Carvalho, R.S., da Cunha, E.G. (2020).
Passive house alternative proposal for the Brazilian Bioclimatic Zone 8. International Journal of Sustainable Development and Planning, 15(6): 827-833. https://doi.org/10.18280/ijsdp.150605

[8] Ramos Ruiz, G., Fernández Bandera, C. (2014). Importance of orientation in building energy-savings. World SB14 Barcelona Conference, Spain. https://www.irbnet.de/daten/iconda/CIB DC28305.pdf, accessed on Dec. 15, 2020.

[9] Gong, X., Akashi, Y., Sumiyoshi, D. (2012). Optimization of passive design measures for residential buildings in different Chinese areas. Building and Environment, 58: 46-57.

[10] Abbakyari, M., Taki, A. (2017). Passive design strategies for energy efficient housing in Nigeria. PLEA2017 Conference, Edinburgh, UK.

[11] Chen, X., Yang, H., Sun, K. (2016). A holistic passive design approach to optimize indoor environmental quality of a typical residential building in Hong Kong. Energy, 113: 267-281. https://doi.org/10.1016/j.energy.2016.07.058

[12] World Atlas (2019). Where is Al Bayda', Libya. https://www.worldatlas.com/af/ly/ja/where-is-albayda.html, accessed on Dec. 22, 2020

[13] Barbour, N. (2020). Libya. Brittanica. https://www.britannica.com/place/Libya, accessed on Jan. 15, 2021.

[14] Climatestotravel.com. (2019). Libya climate: average weather, temperature, precipitation, best time. https://www.climatestotravel.com/climate/libya, accessed 19 Jan. 2019 